\title{
Analysis of CEC Mode of International Cooperation in Vocational Education under the Guidance of "The Belt and Road" Strategy-Taking Chongqing Vocational Institute of Engineering as an Example
}

\author{
Liu Tong ${ }^{1}$, You Shuhui ${ }^{2}$, Liu Yu ${ }^{1}$ \\ 1. Chongqing Vocational Institute of Engineering \\ 2. Beijing Huatec Information Technology Co.,Ltd \\ 1. No.1 Nanbei avenue, Bingjiang new town, Jiangjin district, Chongqing, China 402260
}

2. Building 15, No. 3, Jinghai 5th Road, Zhongguancun Science Park Opto-Mechatronics Industrial Park, Tongzhou District, Beijing101100, China

Email: liuyyshiwo@163.com

\begin{abstract}
Vocational colleges actively respond to the national "The Belt and Road" strategy and participate in the practice of international cooperation in running schools. However, the main body of international cooperation in vocational education is schools, which lacks the effective participation of enterprises, resulting in unsatisfactory results. In order to improve the cooperation, this paper takes Chongqing Vocational Institute of Engineering as an example, proposes a new cooperation mode called CEC for International Vocational education, and makes a detailed analysis of this mode.
\end{abstract}

Keywords-"The Belt and Road"; Vocational education; International cooperation; CEC model

\section{INTRODUCTION}

The National Development and Reform Commission and Ministry of Foreign Affairs and Ministry of Commerce jointly released the Vision and Actions on Jointly Building Silk Road Economic Belt and 21st-Century Maritime Silk Road on March 28, 2015. The document indicated that speeding up the construction of "The Belt and Road" helps to promote economic prosperity and regional economic cooperation among countries along the belt and road, and is a great cause that benefits the people all over the world. Improving international communication interconnection and keeping the information silk road open is an important task for the communication industry to serve "The Belt and Road" strategy [1][2].

With the deepening of economic globalization and higher education internationalization, the international exchange and cooperation of higher vocational education emerge at the right moment especially under the background that China's education industry follows the national "Belt and Road" great strategy. In recent years, the state attaches great importance to the internationalization development of higher vocational education, so the majority of higher vocational colleges take positive actions, actively conduct all kinds of international exchanges and cooperation with foreign colleges and universities such as exchange and visits between teachers and students, joint cultivation of technical skills talents, cultivation of internationalization quality of teachers and technical skills training, have obtained certain achievements and formed a multi-level, multi-form and wide-ranging pattern of international exchanges and cooperation. Some scholars pointed out that higher vocational education in China going to the world can be expected soon, and some higher vocational colleges have taken "going to the world" as their strategic goal [3].

\section{ANALYSIS OF THE EXISTING PROBLEMS}

We should know while obtaining the above achievements that the overall level of the international exchanges and cooperation of higher vocational education is now relatively low, the scale of international cooperation and exchanges is unsuited to higher vocational education development scale and there is a single form of international cooperation and exchanges. The current way of international cooperative school running is mainly University to University (2U for short) model, which lacks deep participation of enterprises, leading to that the early effect of some cooperation projects is better and the final result isn't ideal and international talents meeting the enterprise requirements can't be cultivated. The reasons are mainly reflected in the following three aspects.

The first is the source of students for cooperative school running. The international cooperative school running program of higher vocational colleges usually targets students with the lowest scores in college entrance examination. In terms of learning ability, critical thinking skills and comprehensive quality, there is a certain gap between higher vocational college students and undergraduate students. Most students have a poor level of foreign languages, can't leap over the basic language barrier, and are more unlikely to use foreign languages to learn professional courses. The negligence of basic knowledge makes most students unable to access and master better education resources.

The second is the management system of both sides. Due to the differences of Chinese and western thinking modes and 
behaviors, in the international cooperative school running, it's very difficult for Chinese schools to realize the synchronous teaching operation and management with foreign schools. There are relatively large differences between Chinese schools and foreign schools in aspects of curriculum installation, curriculum construction, teaching mode, teaching organization and implementation, examination and evaluation, scientific research level and teaching staff construction.

The third is that the program lacks the participation of enterprises. The current international cooperation mode is mainly that the schools of both sides as the subject carry out the cooperation. There is a relatively single form and contents and there are no enterprises participating in the whole process of talent cultivation. The cultivated students lack a clear understanding of work, leading to a decline in the quality of employment. After some higher vocational colleges realized this problem in the process of international cooperation, they also invited related enterprises to participate in the cooperation. However, enterprises only act as participants, and don't reflect the deserved value as the subject of cooperative school running, and lack the enthusiasm and initiative to participate in international cooperative school running.

In order to adapt to the economic globalization and the international development of higher vocational education, the international exchange and cooperation of higher vocational education in China should change the traditional way, and explore a talent cultivation mode of CEC (College \& Enterprise \& College) international exchange and cooperation jointly led by schools, enterprises and overseas schools. CE means that the college jointly invests the establishment of a joint talent cultivation base with enterprises, develops the mixed-ownership education, and co-cultures talents needed for the enterprise internationalization development. EC means that the college jointly established "The Belt and Road" silk road international college with enterprises and cooperative universities to train localized talents for international enterprises. The combination of the two constitutes a CEC international cooperative school running model and promotes the sound and fast development of international exchange and cooperation of higher vocational education in China.

\section{ANALYSIS OF NECESSITY AND FEASIBILITY OF INTERNATIONAL CEC MODEL OF HIGHER VOCATIONAL EDUCATION}

\section{A. Analysis of Necessity}

1) Need of "The Belt and Road" Strategy and Local Economic Development for Communication Talents

"The Belt and Road" involves 64 countries, accounting for two-thirds of the global population, one-third of the global economic scale. They are generally in the rising stage of economic development, the acceleration period of infrastructure construction; Their market capacity and talent demand in the communications industry are expected to be 2-3 times those of China, namely 2-3 million people. Improving international communication interconnection and keeping the information silk road open is an important task for the communication industry to serve "The Belt and Road" strategy.
As an important junction node of the Silk Road Economic Belt and the 21st-Century Maritime Silk Road, Chongqing has prominent geographical advantages and important strategic position, and plays a unique and important role in national regional development and opening-up pattern. The first Smart China Expo was grandly opened in Chongqing on August 23, 2018. Jinping XI sent congratulatory messages to the Expo and stressed that China should pay high attention to innovation-driven development, firmly implement the new development concept, accelerate the digital industrialization and industrial digitalization, and strive to promote high-quality development and create high-quality life. China is ready to take an active part in international cooperation in the digital economy and works with other countries to promote the sound development of the digital economy, so as to cultivate new power and new space for the world economic growth.

In terms of promoting intelligent innovation of big data, Chongqing has favorable geographical advantages, policy advantages, industrial advantages, scientific and educational advantages and market advantages. Later, Chongqing Municipal Government issued the Action Plan of Innovationdriven Development Strategy Led by Big Data Intelligence (2018-2020) in Chongqing, which further highlighted the prominent leading role of big data, artificial intelligence and other technologies. Chongqing Communication Administration conducted a survey of the basic condition of talents, talent structure, demand for talents and talent cultivation mode in Chongqing infocommunications industry and issued the White Paper on "Internet +" Talents in Chongqing Infocommunications Industry. The White Paper pointed out that in the current development situation, the talents gap in Chongqing Infocommunications Industry was huge and a lot of talents are needed to promote the vigorous development of big data intelligent industry in Chongqing.

\section{2) Need for Overseas Local Talent Layout of Chinese} Enterprises

With hundreds of thousands of employees, ZTE and its subsidiaries and affiliated companies have had a profound understanding of the importance of local talents in the development of the global market for more than 20 years.

In December 2016, the school planning, construction and development center of the Ministry of Education and ZTE jointly launched "The Belt and Road" industry-education integration and enterprise internationalization development forum. In the forum, Dianping WANG, vice president of ZTE put forward new opinions and ideas for the realization of international talent cultivation through the industry-education integration of school-enterprise cooperation in combination with ZTE's experience accumulated in over 20 years' development all over the world. Dianping WANG held that international talents required by Chinese enterprises needed to have multi-level ability, including language communication and basic capabilities of overseas life, and crucially international perspective, local resources integration, and professional business ability. Such international team can help enterprises realize the implementation and promotion of internationalization strategy. 


\section{B. Analysis of Feasibility}

1) National Policy Supports the Implementation of the CEC Model

In response to the national call, the Ministry of Education's notice on Promoting the Joint Construction of "The Belt and Road" Education Action in 2016 indicated: Promoting the joint construction of "The Belt and Road" provides an opportunity to promote greater opening up, exchange and integration of regional education. The closer cooperation and common action of national education along "The Belt and Road" is an important part of the common construction of "The Belt and Road" and also provides talent support for the common construction of "The Belt and Road". China is willing to expand the people-to-people exchanges, strengthen talent cultivation and jointly create a bright future for education with countries along the Belt and Road. This poses a great challenge to the curriculum system and curriculum content of the existing vocational colleges. In the Actions, the Ministry of Education clearly proposed that higher education, especially higher vocational education, should provide intellectual support and talent support for enterprises to "go out", which set up a platform for China's higher occupation education to go international and strengthen cooperation with enterprises and overseas universities, and provided convenience and opportunities for the implementation of the CEC model.

\section{2) Both Sides of CEC Model Holding have Profound International Talent Cultivation and School-running} Accumulation

Chongqing Vocational Institute of Engineering is a fulltime ordinary higher vocational school organized by Chongqing Municipal People's Government and supervised by Chongqing Education Committee. It was constructed into national demonstration higher vocational college in 2010 . The school has a long history, strong faculty, perfect teaching facilities and advanced teaching equipment. It has established a long-term intercollegiate exchange mechanism with universities in the United States, Canada, the United Kingdom, Australia, South Korea and other countries and carries out the activities in professional cooperation, course certification, vocational qualification certificate, teacher training, student exchange, and education enhancement. It carries out training and technical services for overseas students with Malaysia, Laos, Uzbekistan, Belarus and other countries along "The Belt and Road".

It has a long experience of school-enterprise cooperative teaching with ZTE which conducts the deep cooperative school running with the universities and has accumulated rich experience in school-enterprise cooperation talent cultivation. ZTE signed a cooperation framework agreement with the Ministry of Education and jointly built "the Ministry of Education- ZTE ICT Innovation Base" through the schoolenterprise cooperation. In the base, the ZTE expert team and cooperation colleges jointly developed the talent cultivation program, jointly developed teaching materials, co-built the practice teaching platform, conducted the joint teaching, jointly developed teaching resource database and provided employment support, etc. ZTE actively initiated the establishment of "International Academy of Silk Road" in countries along "The Belt and Road" abroad, giving escort for enterprises' international business and serving the national "Belt and Road" strategy. Currently ZTE has established 16 overseas training centers in Indonesia, Malaysia, India, Pakistan, Ethiopia and Egypt and other countries along "The Belt and Road".

3) The School Has the School-running Conditions to Implement the International Cooperation CEC Model

The Mobile Communications Technology is the key construction major of Chongqing Vocational Institute of Engineering and the backbone major under construction in Chongqing. Chongqing Vocational Institute of Engineering and ZTE signed the Cooperation Agreement on the ICT Industry Innovation Base of the Ministry of Education - ZTE on October 27, 2015. Under the guidance of the Ministry of Education, the two parties jointly established a high-quality teaching team and carried out the construction and operation of the "ICT industry innovation base". In addition, both sides jointly built a fully functional information and communication technology practice teaching and research platform, built and operated the majors fully realizing the school-enterprise cooperative education together, and jointly established a school-enterprise win-win collaborative research system.

"ZTE ICT University" strengthens the cultivation of basic ability, special ability and comprehensive ability of students in school-enterprise cooperation platform. According to the "three" course system of the course structure module, course content projectization and course management standardization, it carries out the "four joint" cultivation mechanism of jointly formulating the training program, jointly implementing the teaching process, jointly developing specialized courses, jointly setting up the student employment service platform, and cultivates the advanced application-oriented talents of Communication Engineering major with "solid foundation, strong ability, innovation and high quality". "ZTE ICT University" aims to cultivate technical personnel by cobuilding with enterprises and introducing a full set of projectbased enterprise training textbooks and corresponding teaching resources according to the course system. A large number of teaching resources, such as micro class, Mooc, case library and test library have been built based on the "cloud integrated platform of shared professional teaching resource database" of Chongqing Vocational Institute of Engineering.

\section{SPECIFIC MEASURES FOR CARRYING OUT THE CEC MODEL SCHOOL RUNNING}

"ZTE ICT University" is the management and operation organization of the cooperative school running. The "University" is under the leadership and management of Chongqing Vocational Institute of Engineering. The "University" adopts the mode of "school leading, enterprise subject, teachers and students participation and school implementation" to carry out the construction and operation. In order to better serve the national "Belt and Road" strategy, the school and ZTE established "The Belt and Road" international college and silk road college on the basis of "ZTE ICT University", to cultivate applied talents of Communication Technology for countries along the Belt and 
Road and ZTE's institutions in the countries along the Belt and Road.

The management team of ZTE ICT University, "The Belt and Road" international college and silk road college is composed of both the university and the enterprise. Specifically including: Dean of College of Information Engineering, professional team leader, ZTE project manager and ZTE enrollment and employment manager (product manager). The dean of the College of Information Engineering is to serve concurrently as the dean of ZTE ICT University, and is responsible for the overall work of ZTE ICT University. The ZTE project manager is to serve as the deputy dean of ZTE ICT University, is the full-fledged member of the enterprise in terms of mixed ownership and responsible for the management of daily work of the cooperation school and teachers of the enterprise; The professional team leader of the school is responsible for the daily management, system construction and professional development of the mixed ownership college. The specific measures of CEC schoolrunning model mainly include the following aspects.

\section{A. Establish Higher Vocational Education International Cooperation Council}

The council is composed of national governments, industries, schools, enterprises and other units on a voluntary basis. It is an organization which carries out the CEC mode school running continuously and steadily, through the establishment of effective operation mechanism. It provides the platform for carrying out the international education cooperation, school-enterprise cooperation, reforming the specialty settings, promoting teaching reform and technical services through the establishment of effective operating mechanism, to achieve the goal of cooperative school running, cooperative education, cooperative employment and cooperative development" between countries and between the country and enterprise. Conduct the deep cooperation between schools of various countries and between schools and cooperative enterprises and sign the cooperative school running agreement. All parties supply funds and make great efforts, jointly assume responsibilities, standardize the relations between responsibility, rights and interests of all parties, and serve the enterprises and expand the enterprise's investment in education by co-building training bases and cultivating talents based on orders. It's the close cooperative school running system mechanism to realize the talent cocultivation, process co-management, achievement sharing and shared responsibility. Through the combination of talent cultivation in each school and enterprise employment plan, all parties jointly study the talent cultivation program, cooperate in education, carry out "double subjects" or order training activities, do a good job in "working and learning alternation" teaching organization, meet the production requirements of enterprises and solve the employment problem of students. In addition, they should also give play to the government's policy advantages, the school's human resources advantages and the enterprise's production equipment advantages, a good environment created by the government and technical services provided by the school, so as to jointly promote the transformation and upgrading of enterprise products; Improve the research and development ability of teachers, continuously improve the connotation of course teaching, improve the quality of talent cultivation, and provide high-quality graduates for enterprises through technical services. At the same time, the council is also responsible for coordinating the relations among all parties and safeguarding their interests. Be responsible for coordinating the relationship between the government, industry, enterprise and school, and coordinating the resources of all parties to support cooperative school running.

\section{B. Set up the International Cooperation Management Office of Higher Vocational Education}

The international cooperation management office is an important functional department responsible for the development and management of cooperative projects and communication matters among schools of all countries, and between the school and enterprise under CED model. Its main job responsibilities are to perfect the internal job responsibilities and management system, earnestly study and implement national foreign policy and higher education policy, adhere to and implement the decisions, conduct the professional ethics education on the internal personnel of the department and provide good services for teachers and students. Based on the school-running thoughts of higher education administrative department on higher vocational education, it should also make the planning and management method of CEC cooperation and organize implementation and constantly innovate the industry-university- research cooperation system mechanism in combination with the actual situation of economic development each country and Chongqing and the objective requirements of talent cultivation. Conduct policy and theoretical research on multilateral cooperation to ensure the sustainable development of such cooperation in terms of systems, policies and management mechanisms. Be responsible for strengthening the contact and communication between schools, enterprises, industry associations and social organizations. Collect social information from various aspects, guide teachers and students to effectively participate in international cooperation, participate in social practice, and serve the society in various forms and channels. Conduct the regular social research activities for cooperation, track, monitor, evaluate and assess cooperation projects, and truly give play to the role of all parties involved in CEC cooperative school running in international cooperation and exchanges, education development and local economic construction.

\section{Develop the Management System and Talent Cultivation Program for Overseas Students}

The work of overseas students of ZTE ICT University follows the CEC model. Based on the principle of jointly promoting and enhancing the internationalization level of vocational colleges and serving "The Belt and Road" strategy and coordinating in China's equipment "going out" and global cooperation on production capacity, give full play to the advantages of government, industry, enterprise and school, recruit international students from countries along "The Belt and Road", cultivate overseas students based on the ZTE overseas local talent demand model and explore and construct 
the new model of higher vocational international cooperative school running and international technical talent cultivation of ICT majors.

It should follow the relevant policies and regulations of the state, local authorities and competent administrative departments and run the school legally in terms of cultivating foreign students in China. When developing the talent cultivation program, it should reflect the student-centered principle, follow the law of the vocational education and the law of physical and mental development of students, insist on integrating the cultivation of professional ethics and professional spirit into the whole process of education and teaching, and promote the all-round development of students. It should basically follow the national teaching standards of vocational education. In combination with the actual situation and employment trend of overseas students from various countries, it should be targeted to design the course system, set the teaching content and ensure tight logic between the course system, teaching content and training objectives. The contents of the program are scientific and reasonable and give due consideration to forward-looking, to ensure the seriousness and operability of the talent cultivation program; Based on international and domestic advanced experience, the program should reflect Chinese characteristics and international level, and the co-construction and sharing of talent cultivation program for overseas students should be promoted in international exchanges and cooperation.

\section{SUMMARY}

The national and local policy support makes the international cooperative school running possible. Many years of school running accumulation of Chongqing Vocational Institute of Engineering and ZTE's technical leadership have laid a solid foundation for CEC school-running model. CEC model has broken the original international cooperative school running pattern and provides a new direction for international cooperative school running. All parties should strengthen communication, carry on the exchange between them and better serve the national "Belt and Road" important strategy.

\section{REFERENCES}

[1] Xiangfen CHEN Research on cooperative innovation talent cultivation mode in higher vocational colleges under the background of "The Belt and Road" Chinese Vocational and Technical Education, 2016 (4): 42 45.

[2] Jian LUO. Research on the cultivation of information professionals in higher vocational colleges under the background of "Internet + " [J]. Vocational \& Technical Education Forum, 2016 (18): 81-85.

[3] Lei ZHU. Research on the path innovation of higher vocational colleges helping enterprises to "go out" under the strategic background of "The Belt and Road" [J]. Chinese Vocational and Technical Education, 2016 (33): 106-110. 